\title{
Plant Characteristics for Green Wall Systems
}

\author{
Endah Budi Irawati*, Basuki \\ Agrotechnology Department, Faculty of Agriculture, UPN "Veteran" Yogyakarta \\ Jl. SWK 104 Lingkar Utara Condongcatur Yogyakarta 55283, Indonesia. Tel. +628121578303 \\ Email*: endahbudi89@gmail.com
}

\begin{abstract}
This research is a preliminary study of planting ornamental plants with a green wall system. This study aims to provide an overview and information about the selection of types of plants that are suitable and commonly used in making green walls and arranging selected plants in green walls system. Green wall system which is often called vertical garden is a technique to plant ornamental plants, vegetables or other types of plants with a free design that considers various resources that allow plants to grow vertically. The advantages of green walls are efficient use of soil, beautifying the environment, adding location value, cleaning the air, lowering temperature, producing oxygen and providing fresh food that is close to the surrounding environment at home. Not all types of plants can be planted vertically. Easy-to-grow plants, short appearance and slow growth are common characteristics used for green walls. The special characters of the selected plants are determined based on the group of indoor or outdoor plants. Consideration of nutritional, light, water and plant requirements will determine the success of planting and the sustainability of vertical planting.
\end{abstract}

Keywords: green wall, vertical garden, plant characteristics

\section{INTRODUCTION}

Green wall is often called verticulture is a vertical planting technique with part or all of the wall / building plant covered with green plants that grow on planting media such as soil, fuel husks, compost, ferns, cocopeat, or other planting media. The Vertical Garden allows man to re-create a living system very similar to natural environments. It's a way to add nature to places where man once removed it (Blanc, 2008). The availability of plant life support elements is an important factor that supports the optimal appearance of plants and the decision in selecting plant species for vertical cultivation. Not all types of plants are suitable for vertical cultivation, this is due to some limitations of the vertical cultivation system. Planting containers and planting media are limited to be considered for plant selection that is not too high and large.

The advantages of growing vertically include efficient use of land, beautifying the environment, adding value to the location, cleaning the air, lowering environmental temperatures, producing oxygen and providing fresh food (vegetables and fruits) close to the home environment. The disadvantages of growing vertically are that sustainability is not guaranteed, requires more initial capital, requires watering automation equipment, needs intensive maintenance, uneven lighting and not all types of plants can be planted vertically (Widyawati, 2018). Plants do not grow optimally, affecting the overall appearance of the green wall. Plants are selected based on climatic conditions, building characteristics and surrounding environmental conditions (Manso and Castro-Gomes, 2014). Other things to consider include indoor or outdoor plants, annual or annual plants, the nature of growth, the ease of plants to grow and the resistance of plants to the environment.

\section{METHODOLOGY}

This study aims to provide reviews and information about selection of suitable types of plants that are commonly used in making green walls and arranging selected plants on green walls. The data source comes from several journals and the author's personal communication with the owner of the ornamental plant nursery.

\section{RESULT AND DISCUSSION}

\section{Plants for the Green Wall}

Plants are living things that always grow and develop. Each plant has its own characteristics that distinguish between one another. The beauty and uniqueness of a plant makes it popular, sought after by many people, has a high price, and is desirable for its presence in a vertical garden. There are several considerations in selecting and placing plants in a vertical garden, namely: 1) Living habits and forms of growing plants. Based on living habits, plants are classified as short-lived and long-lived plants. Short-lived plants consist of annual and bi-annual plants. while plants that have a long life cycle are called perennial plants. Based on the form of growth, plants are grouped into herbs and shrubs 2) Appearance of plants. The visual beauty of plants can be shaped and seen from the branching character, from the overall shape, texture, 
color, and aroma produced 3) Plant attractiveness. Ornamental plants are also grouped according to their main attractions, namely flower ornamental plants and leaf ornamental plants 4) Growth speed and special character of plants. Based on the speed of growth, there are some plants that grow fast, medium and slow. Regarding the diameter of plants, there are plants with a diameter of width, medium and small. Based on the density of the canopy, plants are divided into plants with very close canopy, medium canopy and rarely canopy 5) Distribution of growing plants. There are four zones in plant ecology, namely the hot zone $(0-700 \mathrm{~m}$ asl $)$, the mid zone (700-1,500 $\mathrm{m}$ asl), the cool zone (1,500-2,500 $\mathrm{m}$ asl) and the cold zone (2,500-3,300 m asl) 6) The function of plants in the garden. There are four functions of plants namely architectural functions, beauty functions, engineering functions and climate control functions. In the function of architecture, plants function as forming spaces, limiting unfavorable views and giving privacy to outside spaces. For the function of beauty, plants provide beautiful visual accents such as ornamental plants and add value to a location. The engineering functions of plants include preventing glare (tightly planted plants) and controlling sound. Meanwhile, as a climate controller the plant functions as a shade, limiting wind movement, modifying air temperature and humidity (Hasim S, I. 2009).

Table 1. Types of Ornamental Plants for Green Walls.

\begin{tabular}{|c|c|c|c|c|c|c|}
\hline \multirow[b]{2}{*}{ Types of Plant } & \multicolumn{6}{|c|}{ Plant Classification and living needs for plant growth } \\
\hline & $\begin{array}{c}\text { Indoor } \\
\text { Plant }\end{array}$ & $\begin{array}{c}\text { Outdoor } \\
\text { Plant }\end{array}$ & $\begin{array}{c}\text { Sun } \\
\text { Exposure }\end{array}$ & $\begin{array}{c}\text { Water } \\
\text { requirements }\end{array}$ & Elevation & $\begin{array}{c}\text { Level of planting } \\
\text { Difficulty }\end{array}$ \\
\hline $\begin{array}{l}\text { Anthurium andreanum } \\
\text { (Anthurium) }\end{array}$ & $\sqrt{ }$ & & Moderate/ little shade & Moderate & Highland & Easy \\
\hline Cryptantus bromelioides (Bromilia) & $\sqrt{ }$ & $\sqrt{ }$ & Full sun/ direct light & Moderate & Highland / lowland & Easy \\
\hline $\begin{array}{l}\text { Calathea medallion } \\
\text { (Kalatea) }\end{array}$ & $\sqrt{ }$ & $\sqrt{ }$ & Moderate & A little & Highland / lowland & Easy \\
\hline $\begin{array}{l}\text { Calathea rufibarba } \\
\text { (Kalatea Bulu ayam) }\end{array}$ & $\sqrt{ }$ & $\sqrt{ }$ & Moderate/ little shade & A lot & Highland / lowland & Easy \\
\hline $\begin{array}{l}\text { Coleus merah } \\
\text { (Miana) }\end{array}$ & & $\sqrt{ }$ & A lot & A lot & Highland / lowland & Easy \\
\hline $\begin{array}{l}\text { Dendrobium } s p \\
\text { (Anggrek dendrobium) }\end{array}$ & $\sqrt{ }$ & & Moderate/ little shade & A little & Highland / lowland & Easy \\
\hline $\begin{array}{l}\text { Dieffenbachia sp } \\
\text { (Belanceng) }\end{array}$ & $\sqrt{ }$ & & Moderate/ little shade & A lot & Highland / lowland & Easy \\
\hline $\begin{array}{l}\text { Dracaena golden } \\
\text { (Dracaaena) }\end{array}$ & $\sqrt{ }$ & $\sqrt{ }$ & Full sun/ direct light & A lot & Highland / lowland & Easy \\
\hline $\begin{array}{l}\text { Epipremnum aureum } \\
\text { (Sirih gading) }\end{array}$ & $\sqrt{ }$ & $\sqrt{ }$ & Full sun/ direct light & A lot & Highland / lowland & Easy \\
\hline $\begin{array}{l}\text { Ficus elastica } \\
\text { (Beringin) }\end{array}$ & $\sqrt{ }$ & $\sqrt{ }$ & Full sun/ direct light & A lot & Lowland & Easy \\
\hline $\begin{array}{l}\text { Ixora sp. } \\
\text { (Soka) }\end{array}$ & & $\sqrt{ }$ & Full sun/ direct light & A lot & Highland / lowland & Easy \\
\hline Melpighia coccigerei (Mirten) & $\sqrt{ }$ & $\sqrt{ }$ & Moderate/ little shade & Moderate & Highland / lowland & Easy \\
\hline $\begin{array}{l}\text { Nephrolepis biserrata } \\
\text { (Pakis Bulu) }\end{array}$ & $\sqrt{ }$ & $\sqrt{ }$ & Moderate/ little shade & A lot & Highland & Easy \\
\hline $\begin{array}{l}\text { Ophiopogon japonicus } \\
\text { (Kucai mini) }\end{array}$ & & $\sqrt{ }$ & Full sun/ direct light & A lot & Lowland & Easy \\
\hline $\begin{array}{l}\text { Osmoxylon lineare 'Yellow' } \\
\text { (Aralia, kaki laba-laba) }\end{array}$ & & $\sqrt{ }$ & Full sun/ direct light & A lot & Highland & Easy \\
\hline $\begin{array}{l}\text { Peperomia polybolrya } \\
\text { (Peplon) }\end{array}$ & $\sqrt{ }$ & & Moderate/ little shade & Moderate & Highland / lowland & Easy \\
\hline $\begin{array}{l}\text { Phalaenopsis spp } \\
\text { (Anggrek bulan) }\end{array}$ & $\sqrt{ }$ & & Moderate/ little shade & Moderate & Highland / lowland & Easy \\
\hline Philodendron "Moonlight" & $\sqrt{ }$ & & Moderate/ little shade & A little & Highland / lowland & Easy \\
\hline $\begin{array}{l}\text { Philodendron selloum } \\
\text { (Jari selloum) }\end{array}$ & $\sqrt{ }$ & & Moderate/ little shade & A little & Highland / lowland & Easy \\
\hline $\begin{array}{l}\text { Polyscias guilfoylei "quinquefolia" } \\
\text { (Kedondong Laut Seledri) }\end{array}$ & $\sqrt{ }$ & $\sqrt{ }$ & Full sun/ direct light & A lot & Highland / lowland & Easy \\
\hline $\begin{array}{l}\text { Sanseveria trifasciata } \\
\text { (lidah mertua) }\end{array}$ & & $\sqrt{ }$ & Full sun/ direct light & A lot & Highland / lowland & Easy \\
\hline $\begin{array}{l}\text { Spathiphyllum wallisi } \\
\text { (Spathiphyllum) }\end{array}$ & $\sqrt{ }$ & & Moderate/ little shade & A lot & Highland / lowland & Easy \\
\hline $\begin{array}{l}\text { Zamioculcas zamiifolia } \\
\text { (Zamia) }\end{array}$ & & $\sqrt{ }$ & Full sun/ direct light & A lot & Highland / lowland & Easy \\
\hline
\end{tabular}

Source: Hasim S, I. 2009.

Note: lowland $1-700 \mathrm{~m} \mathrm{dpl}$, highland > $700 \mathrm{~m} \mathrm{dpl}$. 
According to Manso and Castro-Gomes (2014), green walls are divided into 2 types namely green facades and living walls. Green facades use annual plants that creep or hang along the walls while living walls use a support structure to support the growth of plants vertically. Perennial vines that are often used in Green facades include Hedera helix (Ivy), Cissus rhombifolia (grape leaves), Clematis sp (creepy clamps), Ficus pumila (dollar leaves). Living walls develop new beauty concepts from green walls, use various types of plants, develop various design patterns, various colors, textures, leaf shapes and densities, and plant growth. This is combined with the provision of consistent irrigation and sufficient nutritional requirements and this easily adopts the adaptation of the concept of a hydroponic system. It is important to analyze plant development, color, flowering, leaf and plant composition globally, drainage and root development.

The location of the placement of green walls will determine the choice of plant types, namely indoor plants or outdoor plants. Indoor plants require relatively less sunlight compared to outdoor plants. Indonesia is a tropical country, so sunshine is abundant throughout the year. Light is needed by plants for photosynthesis. If the placement of green walls is an open ground condition, the need for sunlight can be fulfilled throughout the day unless it is shaded by large trees around the site or blocked by tall buildings in the vicinity. The optimal light requirements for each plant will be different. Components of sunlight can be seen from the intensity of light, wavelength and photoperiod. The highest light intensity occurs during hot days and usually air temperatures are also high. Light intensity is related to the incident angle of light, the high intensity of light when the angle of incidence is perpendicular to the vertical plane of the green wall. The wavelength of sunlight for photosynthesis between $380-700 \mathrm{~nm}$, so the plant will grow optimally. Long days and long nights in the tropics are relatively the same \pm 12 hours per day, so plants get light during the dry and rainy seasons. Placement of a green wall in the room requires electric light with a certain intensity. The intensity of the light given will determine plant growth optimally. Vertical garden technology in Indonesia is more towards urban life style than the sustainable concept of vertical garden itself seen from the use of vertical garden technology (Ghoustanjiwani, 2011). Some types of plants for green walls can be seen in table 1 .

From table 1 selected 12 types of plants to be arranged in the green wall namely pakis bulu, kaki labalaba, philodendron "moonlight", philodendron selleum, kedondong laut seledri, mirten, kalathea bulu ayam, kalathea medallion, dracaena "golden", kucai mini, coleus and soka.

\section{Arrangement of Plants in Green Wall}

Green wall design takes into account aspects of design principles namely balance, rhythm, accentuation, and design elements such as color, texture and shape (Hakim, 1993 in Prakoso, 2018). Balance is stability or the appearance of equal attraction between parts of one another. Green wall is arranged from selected plants with balance between the right and left side. So the impression of beauty can be evenly distributed along the green wall made. Rhythm is a regular arrangement or repetition of elements or elements in an object of work. Repetition of the same type of plant is made so that the green wall looks beautiful. Accentuation is the center of attention of the preparation of this green wall, namely Philodendron sp "moonlight". Plant color selection is a degradation from green to yellow and also red. The texture is formed from rough and smooth patterns that are not regularly on the surface of the green wall. The difference in leaf shape between philodendron sp, pakis bulu, mirten and other types of plants gives a dynamic impression on the green wall.

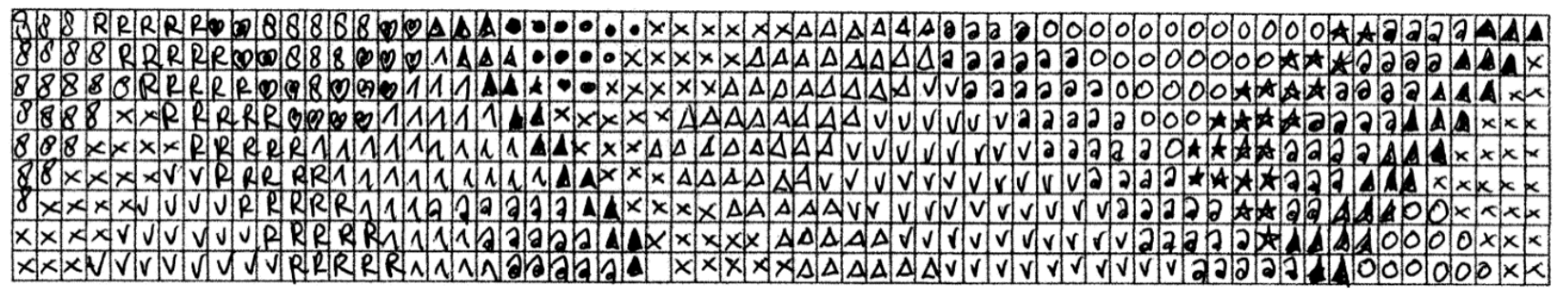

Figure 1. Arranging selected plants in a green wall.

Note: • = Philodendron "Moonlight", $X=$ Calathea rufibarba , $\Delta=$ Dracaena sp "Golden", @= Mirten,

$\circ=$ Calathea "medallion", $+=$ Polycias guilfoylei, $\Delta=$ Aralea, v = Kucai mini, $8=$ Pakis bulu, $\wedge=$ Ixora sp

$\mathrm{R}=$ Coleus,$\quad \bullet=$ Philodendron selleum

\section{CONCLUSION}

1. There are 12 ornamental plants selected for the vertical garden, namely pakis bulu, kaki laba-laba, philodendron moonlight, philodendron selleum, kedondong laut seledri, mirten, kalathea bulu ayam, kalathea medallion, dracaena golden, kucai mini, coleus and soka.

2. Selection of plants based on the characteristics of outdoor plants with little shade and needs of moderate light, medium water, and plants that are 
suitable for the lowlands to mediumlands (1-700 meters above sea level)

3. The selected plant types are arranged in a vertical garden frame based on design principles including balance, rhythm, accentuation and design elements, namely color, texture and shape.

\section{ACKNOWLEDGEMENTS}

Acknowledgments the authors convey to LPPM UPN "Veteran" Yogyakarta who have funded this Applied Research, with the agreement on the Implementation of Applied Research Number: B/286/UN.62/PT/X/2019

\section{REFERENCES}

Blanc, P. 2008. The Vertical Garden in Nature and The City. New York: W.W. Norton.

Ghoustanjiwani, A.P., R. Kusmara and W, Yuniar. 2011. Teknologi Vertical Garden : Sustainable Design atau Hanya Sebuah Trend dalam Urban Life Style ?. Prosiding Seminar Nasional. SCAN\#2 2011. Teknologi dan Arsitektur. II. 580589
Hasim S, I. 2009. Tanaman Hias Indonesia. Penebar Swadaya. Jakarta.

Manso, M. and J. Castro-Gomes. 2014. Green wall systems: A review of their characteristics. Renewable and Sustainable Energy Reviews DOI:10.1016/j.rser.2014.07.203

Prakoso, C dan N, Widyawati. 2018. Perancangan dan Evaluasi Desain Vertical Garden Bertema "Golden Year". Agric 30: $33-42$

Widyawati, N. 2018. Vertikultur; Seni dan Inovasi Berkebun Vertikal. Penerbit ANDI. Yogyakarta. 